\title{
ON THE FORMATION OF A MACKEREL SKY.
}

\section{Br A. H. S. Lucas, M.A., B.Sc.}

On Friday, April 20th of this year, Sydney was favoured with a remarkably extensive and regular display of alto-cumulus clouds, forming a very complete example of that phenomenon which is very rarely seen in these latitudes, a well-developed Mackerel Sky.

I am indebted to Mr. H. C. Russell, F.R.S., the Director of the Sydney Observatory, for the following description of the clouds, taken from his notes made at the time of the appearance.

"In the forenoon a batch of well defined narrow stratus $10^{\circ}$ wide and extending from S.S.W. to N.W., appeared low down W.S.W., and rose gradually, and at noon began to show signs of the cirrocumulus character. At 2 p.m. this was much more decided, and by 3 p.m. the whole W. sky from horizon to zenith, and from N. to S., was covered by the alto-cumulus of the Photograph No. 31 . At the time we were in the middle of a spell of fine weather with $\mathrm{W}$. winds and clear skies. An anticyclone resting over Australia with its centre in lat. $30^{\circ}$. Photograph No. 32 was taken 30 minutes after No. 31. At this time the clouds seemed to have grown larger or nearer. The clouds passed gradually over to the E., and at night, with the moon behind them, looked if anything finer than when the Photographs were taken. No immediate change of weather took place; it was fine and clear before and after. The cloud band was not a feature of the anticyclone then lying over Australia."

The unusually close and regular banding of the clouds, the long parallel rows, rank behind rank, covering more than half of the visible sky, naturally and strongly fixed the attention, and the 
question arose in the mind-How is this wonderful grouping of the clouds produced? Presently the close resemblance of the arrangement of the lines of cloud to that of the low crests of sand on the ripple-marked floor of a wide and shallow bay, forced itself upon me, and led me to consider whether there might not be some real analogy between the two phenomena.

First, then, what are the conditions under which sand ripplemark is produced? We will take the case of ripple-mark formed under water as being more pertinent than that of the ripple marking of blown sand. There are three layers of descendingly denser free particles, a layer of air above, then a layer of water, and a layer of sand grains below. The uppermost layer, of air, moves with a gentle velocity over the surface of the middle layer, of water, and throws this surface into a succession of more or less parallel wavelets. In the open these wavelets range themselves at right angles to the direction of the wind, but near land they tend to conform to the shore-line. If the water is shallow, and the particles of sand are small enough, these last, too, acquire the wave-motion, but with a much slower rate of propagation and with a shorter wave-length.

Have these conditions any correspondence with those under which alto-cumulus clouds are formed? Here too we have a number of horizontal layers of free particles increasing in density as we descend. If an upper layer of the air be moving horizontally over one below it, the lower layer will acquire a wave-motion in precisely the same way as that in which a water surface is thrown into waves by the wind. That this must be the case has been shown mathematically by von Helmholtz. To what vertical depth this wave-motion may extend will depend upon the numbers, depth, density, and the relative motion of the underlying naturally defined layers which may be present.

The wave-lengths of these air-waves will be much greater than those of water-waves, and, of course, very much greater than those of sand-ripples. With a strong horizontal movement of the upper stratum or strata, the wave-lengths of the undulations set up in the lower strata will be greater, and will be accompanied 
by a rapid motion of propagation, or drift. But with a more moderate velocity of the upper layers, the undulations will be on a smaller scale, and the advance correspondingly slower. In a storm, under the influence of a gale of wind water-waves assume their largest dimensions and advance with a greatly increased velocity. When a breeze springs up on a calm day, or as the wind lulls or dies down after a more violent disturbance of the atmospheric equilibrium, smaller, even relatively tiny, wavelets are produced in the water, and these advance with a greatly diminished velocity. It is these lesser wavelets which contribute to the formation of ripple-mark, and similarly, we conclude, it is the lesser atmospheric waves which contribute to the formation of alto-cumulus clouds.

The wave-motion becomes visible under certain conditions. When an air stratum is thrown into waves, the pressure of the air in the ridges of the waves will become less, while the pressure of the air in the troughs of the waves will become greater, than the previous mean pressure of the stratum. The air in the crests will then expand, and its temperature will consequently fall. If an undulating stratum be so nearly saturated with watervapour that a slight reduction of temperature will be sufficient to cause partial condensation, the parallel lines of cloud so formed will reveal to the eye the actual position of the crests of the airwaves.

If, as must happen only rarely, the horizontal layers of different densities are uniformly thick and similar over a wide area, and the horizontally directed wave-motion is not interfered with by uprising vertical currents over a vast stretch of sky, we shall have such a grouping of the clouds as was seen in our typical and magnificently developed Mackerel Sky of April 20th.

The general idea of this explanation of the phenomenon occurred to me whilst admiring this remarkable spectacle, and I mentioned it to others who were with me at the time, including Dr. Harris, the Head Master of the King's School, and Mr. Robin, M.A., of Newington College. About a month after, I observed from a short notice in "Nature" of an important paper published in the 38 
February number of "Himmel und Erde," that a somewhat similar explanation had therein been advanced by the eminent meteorologist, Professor von Bezold. When in Melbourne recently, I obtained access to the periodical in question by the kindness of Mr. R. L. J. Ellery, F:R.S., of the Melbourne Observatory. The subject of von Bezold's paper is Cloud-Building in General, and, amongst the other kinds of cloud, he discusses the mode of formation of the varieties of wave clouds.

After referring to the investigations of Professor von Helmholtz, in which he showed mathematically that waves are produced by the stroking movement of one air-stratum over another of different density and temperature, he writes :- " Diese Wellen werden nun sichtbar sowie die beiden Schichten genügende Feuchtigkeit besitzen. Es werden nämlich an jenen Stellen, welche den Wellenkämmen entsprechen, Massen der einen Schict in die andere hineingetrieben; infolge dessen bilden sich Wolken, welche die Gestalt paralleler Wülste oder Streifen zeigen und für welche Herr von Helmholtz die treffende Bezeichnung der Wogenwolken eingeführt hat."

It will be seen that Professor von Bezold attributes the condensation of the vapour into water or snow particles in the crests of the air-waves to the intermingling of the masses of the air of the two strata, to the forcing of masses of the lower into the upper. He has, however, previously, in another connection, drawn attention to the fact that condensation is exceptionally due to mixture of masses of nearly saturated air at different temperatures. The view I have advocated above, in which condensation is ascribed to the necessary expansion and consequent cooling of the air in the crests, seems more feasible.

Von Bezold remarks upon the sudden and simultaneous formation of these parallel rolls over a large spread of sky :- "Zunächst haben diese regelmässig angeordneten Streifen die Eigenthümlichkeit, dass sie auf grosse Erstreckung hin beinahe gleichzeitig, wie mit einem Schlage entstehen, sei es, dass sich ein grösserer Theil des vorher klaren Himmels plötzlich mit solchen Wolken bedeckt, sei es, dass eine bereits vorhandene Wolkendecke sich mit 
einem Male mit Furchen durchzieht, während die Wolken selber nur langsam weiter schreiten.

"Diese momentane Entstehen paralleler Reihen von Wolken findet sein vollkommenes Analogon in dem Vorgange, der eintritt, wenn ein plötzlich einfallender Wind eine glatte Wasserfläche trifft und dadurch in einem Augenblicke die Fläche mit vielen hunderten von Wellen bedeckt."

This regular and simultaneous starting into view of the rows of clouds seems again to agree better with condensation by expansion in the crests than with mixture of the masses. In the particular exhibition of this form of wave cloud of April 20th the actual formation of the clouds was not witnessed. Mr. Russell noticed them early in the day far away in the W.S.W., when being seen end on as it were, the clouds seemed to form a band of narrow stratus, which on coming nearer resolved itself into Wülst-Cumulus.

As points in favour of the wave theory of formation of these clouds, may be added-

(1) That the general trend of the cloud bands was at right angles to the direction of the air in the upper stratum.

(2) That the drift of the clouds was very slow. It took nearly the whole of the day for them to pass over Sydney.

We have no measurements of the actual height at which the clouds passed, but it must have been considerable.

Mr. Ralph Abercromby in his book "Weather," 1887, calls the Mackerel Sky "one of the rarest skies." Certainly the display of April 20th was on the most unusual seale. The photographs published with von Bezold's paper, and in the "Specola Vaticana," show very much less extensive banding than do those taken by Mr. Russell on this occasion. While the phenomenon of waveclouds may be seen almost every day on a small scale, it must be only exceptionally that a wide horizontal stretch of air, even at a great height, is absolutely free from disturbance by uprising currents, and particularly if this be over a diversified land surface. 
In conclusion, I have to express my indebtedness and thanks to Mr. Ellery and to Mr. Russell for advice and assistance in preparing this statement of the theory. Mr. Russell has most generously allowed me to make use of his photographs and of the notes which he made at the time of the phenomenon.

The ripple-cloud, or wave-cloud, or, to coin a corresponding term, Undulus, should take its place in the classification of clouds by the side of the Stratus, Cumulus and Cirrus, for out of combinations of these elemental forms can be derived most of the diversified and ever-changing cloud-groups which never cease to delight and astonish the eye and mind of man. 


\section{$2 \mathrm{BHL}$ Biodiversity Heritage Library}

Lucas, A. H. S. 1895. "On the formation of a mackerel sky." Proceedings of the Linnean Society of New South Wales 9, 551-556.

https://doi.org/10.5962/bhl.part.18125.

View This Item Online: https://www.biodiversitylibrary.org/item/29750

DOI: https://doi.org/10.5962/bhl.part.18125

Permalink: https://www.biodiversitylibrary.org/partpdf/18125

\section{Holding Institution}

MBLWHOI Library

Sponsored by

MBLWHOI Library

\section{Copyright \& Reuse}

Copyright Status: NOT_IN_COPYRIGHT

This document was created from content at the Biodiversity Heritage Library, the world's largest open access digital library for biodiversity literature and archives. Visit BHL at https://www.biodiversitylibrary.org. 